\title{
A Holistic Review of Public Funding Of Primary Education in Nigeria
}

\author{
Famade Oladiran Afolayan \\ Nigerian Educational Research and Development Council (NERDC) Lokoja/Kaduna Road, \\ Sheda P.M.B. 91, Abuja.
}

\begin{abstract}
Education is a human industry, the more sophisticated it is the more quality products it provides, hence quality Education is necessity for both human and societal development. If we must expect transformation in our political, social, economic and scientific spheres in Nigeria, Quality education at all levels is needed. This paper took a holistic histo-philosophical study of primary education funding in Nigeria. It observed that a lot of lip-service have been paid to this sector of education for long time, in the way of free and compulsory education without adequate human and financial provisions to meet up the demands. The paper further examined the concept of primary education in Nigeria, Historical antecedence of primary education funding from inception.It goes further to take a cursory look at the modalities and sources of primary education funding in Nigeria and the effects of poor funding of primary education in Nigeria. The paper came up with some relevant recommendations
\end{abstract}

\section{Introduction}

The importance of education to human beings cannot be over emphasized. Education has been defined as all efforts, conscious and direct, incidental and indirect, made by a given society to accomplish certain objectives that are considered desirable in terms of the individual's own needs as well as the needs of the society where that education is based. At the onset, it is important to point out that education goes beyond schooling. But schooling at all levels help to achieve the purpose of education. Education is a human right that should be accorded to all human beings solely by reason of being human. Quality education to all citizen is of utmost importance to any nation to advance. Kalusi (2001), argued favorably to this view that a nation which cannot provide good and relevant education for its citizen has no right to expect rapid economic and social development. This view is not far from Obameata's argument that education is the only means an individual can acquire specialized knowledge, skills and character which is a pre-requisite for national development (Obemeata, 1995). Fawehimi (1974) was among the early vocal voice on the reality. He argued that it is education that makes development possible. There are a lot of international human rights instruments that provide for education as a fundamental human right. These include the Universal Declaration of Human Rights (1948), the International Covenant on Economic, Social and Cultural Rights (1966), the African Charter on Human and Peoples' Rights (1981) and the Child Rights Act. The relationship between education and development is well established such that education is a key index of development. It has been documented that schooling improves productivity, health and reduces negative features of life such as child labour as well as bringing about empowerment. It is well known that education opens the door for all citizens to participate in development activities which is majorly to the advantage of the people and when citizens are denied education, they are excluded from the development process, which in turn puts them at a disadvantage vis-à-vis their compatriots with the benefit of education. This is why there has been a lot of emphasis particularly in recent times for all citizens of the world to have access to basic education of good quality. The importance and linkage of education to the development of any society is well known. It has been documented by Amaele, 2006 that;

Education satisfies a basic human need for knowledge, provides a means of helping to meet other basic needs, and helps sustain and accelerate overall development. Another important role of education lies in the fact that it helps to determine the distribution of employment and income for both present and future generations. And education influences social welfare through its indirect effects on health, fertility and life expectancy.

It is in recognition of this importance that the international community and governments all over the world have made commitments for citizens to have access to education. Meanwhile, it has been documented that across the globe, there are inequalities in educational access and achievement as well as high levels of absolute educational deprivation of both children and adults. In order to confront this challenge, the rights based approach, which emphasizes the participation of citizens, has been advocated. Meanwhile, the Declaration of the 1990 World Conference on Education for All (WCEFA) in Thailand, where the universal basic education scheme came into force as a result of Jomtien Declaration for all by the year 2003 and since then there had been different education conferences worldwide such as New Delhi, 1991 Declaration on E-9 Countries, Amman, 1996 Affirmation on pursuit of the goals of Jomtien, Durban, 1998 Statement of Commitment on inter-African 
collaboration for the development of education, O.A.U. Decade of Education in Africa (1997-2006) among others. It was stated at the conference in Article 1 that every person - child, Youth and Adult - shall be able to benefit from educational opportunities designed to meet their basic needs. This declaration was reaffirmed at the World Summit for Children also held in 1990, which stated that all children should have access to basic education by the year 2000. The World Summit for Children placed a lot of emphasis on raising the levels of female literacy. The most recent one was the Dakar, 2000 World Education Forum which made most African governments to embrace Education for All (EFA) by 2015 as an integral part of their poverty reduction strategy. In a bid to achieve education goals, the Dakar World Education Forum was held as a follow-up meeting to the WCEFA where new sets of goals were set to be attained by the year 2015. The goals include:

i. Expanding and improving comprehensive early childhood care and education, especially for the most vulnerable and disadvantaged children;

ii. Ensuring that by 2015 all children, with special emphasis on girls, children in difficult circumstances and from ethnic minorities have access to and complete free and compulsory primary education of good quality;

iii. Ensuring that the learning needs of all young people and adults are met through equitable access to appropriate learning and life skills programmes;

iv. Achieving a 50 percent improvement in levels of adult literacy by 2015 , especially for women and equitable access to basic and continuing education for all adults;

v. Eliminating gender disparities in primary and secondary education by 2005 , and achieving gender equality in education by 2015, with a focus on ensuring girl's full and equal access to and achievement in basic education of good quality;

vi. Improving all aspects of the quality of education, and ensuring excellence for all, so that recognized and reasonable learning outcomes are achieved, especially in literacy, numeracy and essential life skills.

Four of the Dakar goals (Goals 1,2 3 and 6) address the issue of quality education. Similarly, the Millennium Developments Goals (MDGs) adopted in September 2000 at the United Nations Millennium Declaration has two of the eight goals devoted to education. They are goal 2 (to achieve universal primary education) and goal 3 (to promote gender equality and empower women).Meanwhile, a detailed study of this statement shows that the revolving issue in the process factor in education is adequate funding and management of available resources, the curriculum of study will be improved, necessary instructional materials provided, quality and quantity of teachers could be trained, recruited and retained and require teaching and learning facilities and environment would be achieved if education is given its priority with adequate funding. This then will mean the realistic attainment of quality output, which is quality manpower development.

No doubt, Nigerian education has for long suffered from inadequate funding and gross mismanagement of resources. To this end the quality of our education is in coma. This sympathetic situation anchors this study. This research is intended to critically examine the extent to which primary education is funded in Nigeria and its implication to the nation and education system.

\section{Primary Education In Nigeria}

Section 2C of the National Policy on Education (FRN, 2013) describes primary education as the education given to children aged $6-12$ years. It further acknowledged that, since the rest of education system is built upon it, the primary education level is the key to success or failure of the whole system. Primary education is the foundation of our formal education system. It is expected, at this level that every child at the age of six years should be admitted to the primary school which have a six years duration. Primary education does not only lay foundation of other level of education in Nigeria and other nations but it is the foundation of the sociopolitical and economic advancement of any nation (Nigeria inclusive) (Amaele, 2006). The truth is that no matter how magnificent a building may seem or how expensive it may be, if it lacks solid foundation, it is doomed to collapse. It may not only collapse, causing economic waste, but may result to the death of it occupants.

The Six cardinal objectives of the Primary education in Nigeria, according to the National Policy on Education (FRN 2013) are to

a) Inculcate permanent literacy, numeracy and the ability to communicate effectively;

b) lay a sound basis for scientific, critical and reflective thinking;

c) promote patriotism, fairness, understanding and national unity;

d) instill social, moral norms and values in the child;

e) develop in the child the ability to adapt to the changing environment; and

f) Provide opportunities for the child to develop life manipulative skills that will enable the child function effectively in the society within the limits of the child's capability. 
It was made clear in the policy that "In pursuance of these objectives, "Primary education shall be compulsory, free, universal and qualitative". Therefore, from the cardinal objectives above, primary education input is expected to produce two category of Nigerians. The first are those who would prepare physically, mentally, socially, morally and spiritually to functionally serve and contribute to the development of the sociopolitical and economic growth of the nation. The other category are those who would be admitted to study, in the post primary institution within and outside the country. It is therefore important to state clearly that, any mistake made in producing substandard quality manpower at this foundation level, will produce a recurring problem in all facets of the society.

This was strongly accepted in Akinyemi, (1982) Identification of some basic problems of primary education which includes:

i. Expansion of primary education without due regard to adequate teacher strength.

ii. General lack of systemic planning of primary education activities.

iii. Haphazard school inspection by ministry inspectors.

iv. Inadequate and insufficient instructional material-textbooks, modern teaching aids.

v. Inadequate financing and poorly managed resources.

vi. Ineffective management of schools

vii. Obsolete supervisory techniques by teacher educators.

viii. Over enrolment resulting in overcrowded classroom.

ix. Poor physical facilities- school building and classrooms.

These observations above were made over two decades ago but the situation on ground is more sympathetic. A close look at the observed items above shows that almost all the listed items above rest squarely on inadequate funding especially item $\mathrm{i}$, iv v, vii, viii and ix because with adequate funding and prudent management, adequate teachers strength would be enhanced and overcrowded classroom averted. Also the problem of inadequate and insufficient instructional materials would not have existed. Similarly the issue of physical facilities would have been settled. In line with this, Morphet (1975) argued that, "the financial provisions for education established the limit with which schools and educational institutions must operate; they also determine the quantity and quality of education it provides". Agheta (1984) corroborate this view, maintaining that the success of any school rests on the resources made available to it. He argued that all other vital element in the school can be obtained if adequate fund is made available.

Certainly, it is evident with the views above that, if primary education in Nigeria is to meet up the genuine desires and needs of the nation, it must be adequately funded and prudently managed. But, how then is this level of education funded?

\section{Historical Perspective Of Funding Primary Education In Nigeria}

Western education came into Nigeria through the European missionaries, in 1840s. This move was, Partly in response to the invitation of some of the ex-librated slaves from the Yoruba land and the zeal on the part of the missionaries to evangelize ( Amaele, 2003).

Between 1842 and 1872 the funding of primary education in Nigeria was purely on charity. In other words schools were funded by the various missions through the Sunday (Church) collection and donations from parents (home) churches. This affected the early expansion of education in Nigeria in quantity and quality. Public interest in the funding of primary education in Nigeria came in gradually in 1872 when the then colonial government released the sum of thirty pounds to the three leading missions; Christian Missionary Society (CMS), Wesleyan Methodist and the Roman Catholic Mission. The grant-in-aid was increased to three hundred pounds annually in 1874 and in 1876 it was further increased to six hundred pounds. (Fafunwa 1974).

From 1882 the colonial government interest in education began to increase, not only in the area of funding (grants) but, also in policies. It issued an education ordinance in 1882,1887,1916 and 1926 Education Codes. The grant given by the colonial government was specifically for school building and teachers' salaries (Osokoya 1995). The period 1901-1952 witnessed more of educational financing by the missionaries and voluntary agencies than the colonial government. The 1926 Education ordinance actually laid the foundation of the Nigerian education system (Adesina 1977) the ordinance differ from the 1882 ordinance in the sense that it allowed for the inspectors of the schools to group schools into A, B, C and D categories according to the level of efficiency and tone of the schools. Although the native administration expended various amount of money on education in the southern province, much money was spent on education by the voluntary agencies. In the Northern Province, some pupils in the elementary schools were exempted from paying school fees on ground of poor parental socio economic background. Majorly this educational development was recorded in the south. In the northern part of the country where Islam culture look precedence over western culture, it took the diplomacy of Lord Lugard and others to arrange for secular education programme there. Therefore, the education was jointly controlled and founded by both the colonial government and the emir (Osokoya 1995).Despite the effort 
made by the various mission bodies, the colonial government, the emir (in the north), organizations and individuals in the establishment of primary education, inadequate funding was still observed as one of its major constraints, hence this resulted in low patronage, acceptance and coverage of this foundation level of the education system

In 1951 the colonial government in Nigeria, through Macpherson Constitution empowered the three region in Nigeria (North, East and West), to make law and regulations on education within their own jurisdiction. The western region then under the Action Group government led by Chief Obafemi Awolowo launched free and compulsory primary education in 1955. A lot of public fund was allocated to education in the region to the point that other sectors began to suffer starvation of fund. Taiwo (1982) observed that primary school enrolment rose from 456,000 in 1954 to 811,432 in 1995 while the regional funding of education increased from 2,223,390 pounds in the 1953/54 to 6,306,495 pounds in the 1955/56 session. The Eastern region launched their own free primary education in 1957 , but it was less successful as compared to their western counterpart.

Nevertheless, both the Banjo commission and the Dike commission set up by the western region and the eastern region respectively advised that it would take each region close to their total annual budget to run an effective and efficient universal free compulsory primary education (Osokoya,1995). The report of the commissions, which was highly advisory, affected public funding of education in the regions and concept of free and compulsory primary education.

Public funding of primary education before and after independence became a regional affair. The richer and more visionary the government the more funds are allocated to the region. In 1974, General Yakubu Gowon made an open declaration of his interest in free primary education, but was ousted in 1975. His successor Late General Muritala Mohammed, followed up this dream but could not live to execute it before he was killed in 1976. General Olusegun Obasanjo who succeeded him transformed the ideas to action in 1976. From then, primary education nationwide became "free and compulsory" in principle Amaele, (2006) asserted, he went further to stress that although the history of universal free primary education in Nigeria has witnessed a lot of expansion and numerical growth of schools at the primary level, the quality has always been issue of concern. There seem not be a balance between increase and adequate funding to make for the desired quality.

\section{Modalities/Sources Of Primary Education Funding In Contemporary (Nigerian) Society}

The National policy on education states clearly that education in Nigeria is no more a private enterprise but a huge government venture that has witnessed a progressive evolution of government's complete and dynamic intervention and active participation (FGN, 2013). From the above introductory statement, the government of Nigeria, in principles, assumed sole proprietorship of education. Although it has not been easy to have a reliable and comprehensive statistics of amount of funds coming from government to primary education (Hencliffe 2002 cited in Okeke, 2005) but the Federal Government provides, by law , not less than 2 $\%$ of its Consolidated Revenue Fund (CRF) as intervention to state for the implementation of the UBE programme with the criteria for fund utilization of UBE intervention fund to the states and Federal Capital Territory as pre-primary Education (5\%); primary Education (6\%) and junior secondary level (35\%) Anibueze \& Okwo, 2013, UBEC, 2014).

The $2 \%$ CRF is disbursed to the states in the following proportions:

1) $50 \%$ as matching grant (i.e. fund contributed by both Federal and state government, on equal basis). The none-matching grants include;

2) $14 \%$ fund to address Educational Imbalance among and within states.

3) $0.5 \%$ incentive to states for good performance

4) $2 \%$ funds for the education of the physically and mentally challenged children

5) $2 \%$ funds for monitoring of UBE programmes.

6) $10 \%$ for teachers development

7) $15 \%$ for instructional materials

The Education decree No of 1993 stipulates that all companies operating in Nigeria with a minimum of 100 employees are required to contribute 2.0 percent of their pre-tax earnings to the Education Tax Fund for the purpose of funding Education (Okeke, 2005). But with the revised National policy on Education, this Education Tax has been pegged to $1.5 \%$ as against the formal $2.0 \%$ (FGN, 2013). Therefore, the Federal intervention in UBE is funded through the $2 \%$ of the Consolidated Revenue Fund (CRF) of the Federal Government, the funds/Contribution in forms of Federal Government Guaranteed credits and local/International donor grants. The federal intervention fund to states will be used for the purpose of broadening access, improving quality and

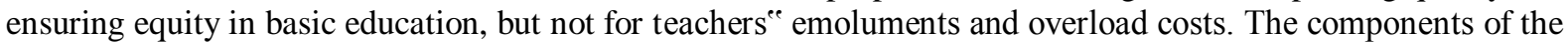
intervention are as follows: 
a. Substantial party of the CRF will be disbursed to states as matching grants;

b. Part of it will be disbursed to states for special intervention to support

1) Initiatives by states to correct educational imbalance

2) Efforts by states to provide special education for the physically and mentally

3) challenged;

4) Efforts by states to implement school feeding program.

5) Disbursement of funds to states will be through SUBEBS, for renovation, construction,

6) furnishing,

c. Disbursement of grants to states will be dependent on the provision of 50\% counterpart funds by states.

d. UBEC may withhold further disbursement to a state if it is not satisfied that funds earlier disbursed had been judiciously utilized.

To access the funds, all states shall present acceptable annual implementations plans based on EFA/MDGS and those projects and program that address their peculiar educational problems (UBEC, 2004). State governments also fund education. Their source is primarily their allocation from the federal account, their state VAT and state generated revenue through local taxes, school levies etc. States fund mainly secondary level of education and a significant part of tertiary education which the state established themselves. Earlier than April 2002, they were not involved in funding primary education when funding meant for primary education was not channeled to states. But since April 2002, states control and fund primary education with funds sent specifically for primary education through UBEC. Local governments are also involved in funding education at the primary school level. Local government revenues come from statutory allocations from Federal Account proceeds from VAT and internally generated funds. On the teacher's salaries, State government is responsible for secondary school teacher's salaries, why the deductions from local government allocation which is channels to SUBEB account is used for the primary school teachers salaries in other words, primary school teacher's salary is a local government responsibility.

But in reality, with all these intervention from the three ties of government above, Government: investment in education falls short of public expectations. The percentage revenue allocation to education has been grossly inadequate. UNESCO, for instance, believes that education sector to be properly rejuvenated and offer the much needed impact, governments of member countries ought to channel at least 26 per cent of their national budgets to education alone. But is not news that, for so many years after the official pronouncement of Universal Basic Education in Nigeria, Nigerians are told that the solution is not in view. For instance, On $4^{\text {th }}$ October 2002, the chairman, House of representative committee on education, Dr, Matazu was reported to have stated that the allocation of 26 percent of annual federal budget to education as recommended by UNESCO is not feasible, he said UNESCO suggestion is laudable but could not be implemented " because other sector needed equal attention. (Amaele, 2006).

Even though the Federal Government of Nigeria has received commendations from stakeholders for appropriating N426.53 billion to education in the 2013 budget, a critical examination of the entire N4.92trillion (\$32billion) budget proposal presented by President Goodluck Jonathan to the seventh National Assembly clearly showed a modest increase by only five per cent from that of N4.697 trillion in 2012.(Daily Independent, 2013)

Relying on the benchmark advocated by UNESCO, it is still implicit that the education sector still faces the problem of inadequate funding. A cursory analysis into the 1999 and 2001 budgetary provision for education showed that 16.77 per cent and 4.08 per cent of the country's budget went to the sector; in 2011 it got 10.24 per cent. While in 2013 budget it represents 8 percent, a far cry from the 2011 appropriation.

Therefore, Nigeria is one of the countries within the African continent that has been termed educationally disadvantaged and almost at its precipice, owing to a myriad of problems bedevilling the sector. Chief among these constraints remain the issue of poor funding of the sector, for which the United Nations Education and Scientific and Cultural Organization (UNESCO) and other stakeholders have consistently advocated for an increase.(Daily Independent, 2013)

A lot of reasons have been advanced for the poor funding of education in Nigeria, these includes lack of genuine focus in education by government, this shows that adequate priority attention is not given to education resulting to careless and unrealistic budgetary provisions: none enforcement of Decree No. 17 of 1993 Education Tax; Inadequate educational statistics in terms of student enrolment, number of classes and other facilities; unsteady economic growth resulting in unending importation and inflation; political instability caused by self centered corrupt leadership and corrupt followership (Amaele, 2006).

\section{Effects Of Poor Funding Of Primary Education}

Poor funding for education effects the younger generations of people, the same people that will be running our country in the future. Poor funding leads to schools having to cut down on supplies that are needed 
to give children a proper education. For example, books are in a short supply, computers, or research sources are in short supply, budgets get too low to have any educational field trips, teachers are not being paid well, therefore leading to less interest in that occupation. Schools need funding to be able to run and to be able to give children the proper education that they deserve. X-raying the plight of teachers generally, occasioned by poor funding Denga (1997) observed that the inadequate salary paid to teachers make teachers vulnerable to ridiculous lifestyle. Some of them, he observes still manage to teach without salary for moths, while most of them, cannot do any honest work. They engage, therefore, in low-cost behavior such as negotiating grades with students for financial exchange as well as sale of examination papers, etc. This has resulted into poor education standard at primary level, lots of out of school children and dilapidated structures of existing schools which has remained unmaintained as a result of this financial deficiency to primary education.

Poor inadequate funding is also consequential to the unfavorable school environment observed today. It is no more a secret that some of our primary school pupils learn under unconducive environments like dilapidated classrooms, under trees and other unsafe circumstances. In some of the schools where classroom exits, pupil either squat, stoop or sit on rough floor to learn. Commenting on education facilities Denga further said that educational facilities have lamentably dwindling and the reading materials in our library have become obsolete. He observed that rush to quick money rather than quality education appears to be main objective.

Money indeed is needed to train, retrain and develop the primary school teachers, to put $u$ new buildings and other learning and teaching facilities as well as maintain the existing ones for effective functioning of the school. This view was aptly upheld by agheta (1984) stating that the success of any school rests on the resources made available to it He argued that all over vital elements in the school can obtained if adequate for is made available.

Regrettably, the National Primary Education Commission (NPEC) survey of 1990/1991 revealed that about $4.9 \%$ of schools in the country have no school building. In some states the situation is unbearable. Fir instance, Benue state has (21.24\%), (Oyebamilade 2003). The same also revealed that there is the acute shortage of teachers' and pupils furniture to the level of $62.5 \%$ and $62.4 \%$ respectively. The story remain the same as of today, poor funding and mismanagement of available resources affects virtually every aspect of our education. Abisogun-Alo (2002) vividly acknowledges the fact that "education cannot be prosecuted in vacuum." She observed that:

The buildings for teaching and learning in any institutions are too few for efficient education delivery. They are also frankly dilapidated and outdated.... Most schools have no libraries. Those with rooms/spaces so designated-have scant, outdated material to show. The school programmes too, are often unworthy. Poor funding result to poor and unhealthy school environment leading to pupils, and staff being exposed to diseases, accidents and consequent death. For instance, some of the dilapidated buildings could collapse on some pupils wounding or killing them. The leaking roofs and open classes may also cause pneumonia (cold) and other adverse health hazards. It may also discourage the pupil's interest in schools, thus leading to early drop out. Poor funding could result to massive failures and poverty.

\section{Conclusion}

Primary education is the foundation of our education system, it constitutes a significant aspect of Nigeria education, apart from providing the necessary foundation upon which the rest of the education system is built, it also serves as the only source of secondary education intakes. The national policy on education describe this sector of education as the key to the success or failure of the whole system. The importance attached to this level of education made the federal government to declare it a tuition free, compulsory and universal (FGN, 1998)

Its therefore disturbing that studies across the country shows the existence of qualitative education as observed in the increased number of primary schools and intake of pupils, ut vey low quality in terms of the output produced. This is mainly caused by inadequate funding. The same average percentage of funds (even sometimes decreased) is allocated to education without considering the increased number of pupils enrolment, this results to lack of human and material resources, un-conducive learning environment, poor facilities, general indiscipline among staff and pupils as well as threatened motivation of teachers and pupils.

\section{Recommendations}

Considering the forgoing, the paper recommends that

1. Twenty six percent of the national, state and local government annual budget should be allocated and properly managed for education as UNESCO demands.

2. Government should review and commenced proper implementation of education tax to make various companies remits $2 \%$ of their annual income to education and a monitory team from government anticorruption agency should be set up to ensure the judicious use of the resources allocated. 
3. Government should look into other sources of financing education in Nigeria such as raising bank loans for capital development, introduction of property tax, donation from endowment, parent-teachers association, alumni association and taxes from lotteries to finance primary education.

4. Government should give primary education its desired priority of free compulsory and universal education, as a lot of lip-service has been paid to this level of education for a long time. Therefore a policy plan with strong monitoring to ascertaining a "totally free" education at primary level should commenced.

5. Government should develop a realistic primary school data-bank as this will help in adequate planning and funding of this level of education, for its success has a lot of positive implication to the entire education system.

\section{References}

[1]. Abisogun-Alo, O. (2002)'Problems in the education sector X-rayed" This day Wednesday December 18

[2]. Adesina, K, et al (1990) (ed) Nigerian Education: Trends and issues. A Publication of the institute of education, University of Ilorin, Ilorin.

[3]. Adeyinka A.A (1993)' Crises in Nigeria Education: Issues at stake' Nigeria journal of educational foundations.

[4]. Adeyemi T.O (2011) Financing Education in Nigeria: An analytical review department of Educational foundations and Management, University of Adeo-Ekiti. Nigeria.

[5]. Aghenta, J.A (1984) "Towards a systematic approach to primary or secondary education in Nigeria" in Adesina, Segun et al (ed) Secondary education OAU Ile-ife press.

[6]. Akpotu, N .E (1988). "Problem of financing education in Nigeria' in P.O itedjere (ed) Currentissues in Nigerian educational system. Benin City: Osasu Publishers.

[7]. Amaele, S. (2006) Public funding of Primary education in Nigeria: Journal of Curriculum Studies, Vol 13.

[8]. Denga, D.I (1997)" Maintaining education standard in a depressed Economy: the case of tertiary education in Nigeria" A convocation lecturer at the federal college of education Obudu, Cross river state, May 9.

[9]. Federal Republic of Nigeria (2013) National Policy on Education. Draft copy (yet to be published) Yaba Lagos NERDC Press.

[10]. Innocent, O. (2013) 'A case for better educational funding in Nigeria, Abuja: Daily independent newspaper

[11]. Kalusi, J.I (2001) Teacher quality for quality education in Nigeria" in Nigerian Journal of educational Philosophy.

[12]. Obemeata, S.O (1995) Education: An unprofitable industry in Nigeria. Post Graduate school interdisciplinary research discourse. Ibadan: University of Ibadan press.

[13]. Olawepo, G. (2004) Education sector underfunded during the military era" Lagos: The Saturday punch newspapers $17^{\text {th }}$ Decenber.

[14]. Omotade, D.(2004)" Nigeria's economy grew by 5\% in 2003", Lagos: The punch 13,17 August.

[15]. Onifade, A. (2003) 'The funding problem', Vanguard education \& manpower $19^{\text {th }}$ January.

[16]. Oshokoya, I.O (1995) History and policy of Nigeria Education in World Perspective. Ibadan AMD Publisher.

[17]. Otive I. (2006) Financing Quality Basic Education in Nigeria. A paper presented at the keynoteaddress delivered at a round table organized by common wealth Education, Abuja Nigeria.

[18]. Samuel, A. et al (2006) Funding Universal Basic Education in a Depressed Economy: The Case of Nigeria. Ile-ife University of ife press.

[19]. Taiwo. C.O (1982). The Nigerian Education system: Past, present and future. Ikeja Lagos Thompson \&Nelson Ltd

[20]. Wokocha, A.A "Education as a human right. Nigerian Journal of educational Philosophy, Vol. VII, No. 1. 